Article

\title{
Physicochemical Characteristics of Individual Aerosol Particles during the 2015 China Victory Day Parade in Beijing
}

\author{
Wenhua Wang, Longyi Shao * ${ }^{D}$, Jiaoping Xing, Jie Li, Lingli Chang and Wenjun Li \\ State Key Laboratory of Coal Resources and Safe Mining, College of Geoscience and Surveying Engineering, \\ China University of Mining and Technology (Beijing), Beijing 100083, China; whwang91@126.com (W.W.); \\ xingjiaoping@126.com (J.X.); jieli_lj@163.com (J.L.); linglilp@126.com (L.C.); liwenjun_620@126.com (W.L.) \\ * Correspondence: ShaoL@cumtb.edu.cn
}

Received: 17 December 2017; Accepted: 23 January 2018; Published: 25 January 2018

\begin{abstract}
During the 2015 China Victory Day parade control periods, the air quality in Beijing hit the best record, leading to 15 continuous good days with an average $\mathrm{PM}_{2.5}$ mass concentration $18 \mu \mathrm{g} / \mathrm{m}^{3}$, which provided a unique opportunity to study the ambient aerosols in megacity Beijing. The morphology and elemental composition of aerosol particles were investigated by transmission electron microscopy coupled with energy dispersive X-ray spectrometry (TEM-EDX). Five types of individual particles were identified, including homogeneous mixed S-rich particles (HS; $44.9 \%$ ), organic coated S-rich particles (CS; $34.3 \%)$, mineral particles $(10.5 \%)$, soot aggregates $(7.21 \%)$ and organic particles $(3.2 \%)$. The number percentage of secondary particles (including HS and CS) accounted for a large proportion with $79.2 \%$ during the control periods. The average diameter of secondary particles increased with relative humidity (RH), being $323 \mathrm{~nm}, 358 \mathrm{~nm}$ and $397 \mathrm{~nm}$ at the $\mathrm{RH} 34 \%, 43 \%$ and 53\%, respectively, suggesting that the high $\mathrm{RH}$ might favor the growth of secondary particles. The higher proportion of CS particles may show great atmospheric implications and the CS particles may be formed by the condensation of secondary organic aerosols on pre-existing S-rich particles.
\end{abstract}

Keywords: morphology; aerosol particle; mixing state; S-rich particles

\section{Introduction}

Atmospheric aerosols, both derived from anthropogenic and natural sources, are composed of various kinds of organic and inorganic species. They have received much attention in megacities in China because they are involved in a multitude of climate and environmental issues [1]. Air pollution can cause a great impact on human health, such as respiratory and cardiovascular problems due to their association with toxic matters [2,3]. Aerosol particles can influence atmospheric chemistry because they can act as a medium for heterogeneous reactions. They can also change the climate indirectly by cloud condensation nuclei $(\mathrm{CCN})$ activity and ice nuclei activity $[4,5]$ and directly through light absorption and scattering [6,7]. Various anthropogenic aerosols can undergo long-rang transport, which can cause a regional and global environmental problem [8].

Recently, China has experienced serious atmospheric pollution due to rapid social and economic development, similar to that in developed nations [1]. The air pollution is characterized by high $\mathrm{PM}_{2.5}$ mass concentration, frequent occurrences of haze days, expanded haze areas, and increased duration of a single haze event [7,9-12]. For example, extremely severe and persistent air pollution occurred in China during January 2013, with more than 1.3 million $\mathrm{km}^{2}$ and 800 million people being affected [1]. Air pollution has been a concern for decades. 
The tropospheric aerosol is a heterogeneous mixture of various particle types. Detailed knowledge of the chemical composition, physical state, morphology and size of individual aerosol particles should be known to fully understand the formation mechanism of regional haze episodes and to accurately predict the climate effects $[13,14]$. A high-resolution transmission electron microscopy (TEM) can be used to investigate the composition, morphology and mixing state of individual aerosol particles.

Understanding the relationship between source emissions and aerosol chemistry is important for mitigating air pollution in megacities [15]. In order to guarantee good air quality during some specific events, e.g., the Beijing Olympic Games in 2008 [16] and the Asia-pacific Economic Cooperation summit (APEC) in 2014 [17], the municipal government launched strong environmental control measures in Beijing and its surrounding areas, which provided some special experimental opportunities to study the impacts of source emission controls on air quality and the physicochemical properties of aerosol particles during clean-up control period. Similarly, a series of temporary control measures, including stopping construction activities, shutting down power plants and factories, limiting the number of vehicles on road and prohibiting outdoor barbecues, were implemented in Beijing and surrounding regions from 20 August to 3 September to ensure good air quality during the 2015 China Victory Day parade [15]. As a result, the air quality hit the best record in Beijing, leading to 15 continuous good days; the average $\mathrm{PM}_{2.5}$ mass concentration was $18 \mu \mathrm{g} / \mathrm{m}^{3}$ during the control period, with a $73.1 \%$ reduction compared with the same period in 2014 (http:/ / www.gov.cn/xinwen/2015-09/07/ content_ 2926447.htm). In this study, the characteristics of individual aerosol particles during the 2015 China Victory Day parade were analyzed by a high resolution TEM.

\section{Experimental}

\subsection{Aerosol Sampling}

The sampling site was located at China University of Mining \& Technology, northwestern part of urban Beijing which is surrounded by commercial buildings and residential apartments. The sampler was placed on the top floor of a five-story teaching building. Cooper TEM grids coated with carbon film (300-mesh copper, Tianld Co., Beijing, China) were used to collect the aerosol samples. A single-stage cascade impactor with a $0.5 \mathrm{~mm}$ diameter jet nozzle and an air flow of $1.0 \mathrm{~L} / \mathrm{min}$ was applied. The collection efficiency of this kind of sampler is close to $100 \%$ on a $0.5 \mu \mathrm{m}$ aerodynamic diameter if the particle density is $2 \mathrm{~g} / \mathrm{cm}^{3}$ [18]. To avoid the particle overlapping on subtracts, the sampling time ranged from 60 to $90 \mathrm{~s}$. A kestral 4000 pocket weather meter (Nielsen-kellermann Inc., Boothwyn, PA, USA) was simultaneously applied to record the $\mathrm{RH}$, temperature (T) and pressure (P). All collected samples were placed in dry and sealed plastic tubes and stored in a desiccator of $25^{\circ} \mathrm{C}$ and $20 \pm 3 \%$ $\mathrm{RH}$ to avoid exposure to ambient air before laboratory analysis [19]. The sample information is shown in Table 1.

Table 1. Information on analyzed samples from Beijing.

\begin{tabular}{ccccc}
\hline ID & Collection Date & $\mathbf{T}\left({ }^{\circ} \mathbf{C}\right)$ & $\mathbf{R H ~ ( \% )}$ & $\mathbf{P ~ ( h P a )}$ \\
\hline $\mathrm{A}$ & $2015 / 8 / 28$ & 34.8 & 34.3 & 1000.1 \\
$\mathrm{~B}$ & $2015 / 9 / 3$ & 29.3 & 43.5 & 1005.1 \\
$\mathrm{C}$ & $2015 / 9 / 2$ & 27.2 & 53.3 & 1006.5 \\
\hline
\end{tabular}

\subsection{TEM Analysis}

Individual aerosol samples were analyzed by TEM (Hitachi H-8100, Hitachi, Ltd., Tokyo, Japan) with an accelerate voltage of $200 \mathrm{kV}$. Elemental composition was semi-quantitatively determined by energy-dispersive $X$-ray spectrometer (EDX) with a spectral acquisition time of $\sim 30 \mathrm{~s}$ and elements heavier than $C(Z \geq 6)$ can be detected [20]. Copper $(\mathrm{Cu})$ was not included from our analysis because the TEM grids were made of $\mathrm{Cu}$. The distribution of aerosol particles on TEM grids was not even with coarser particles in the center and finer particles in the periphery. Therefore, three areas of each 
sample were selected from the center to the periphery to ensure representative data. An image analysis software (Leica Microsystems Image Solutions Ltd, Cambridge, UK) was used to obtain the equivalent circle diameter of particles [21]. A total of 810 individual particles were analyzed.

\section{Results}

\subsection{Nature of Individual Aerosol Particles}

TEM-EDX can be used to adequately characterize the individual aerosol particles. Based on their possible sources, we classified the aerosol particles into two groups: primary and secondary particles, which were further classified into five types as shown in Table 2. The primary particle group included soot, organic and mineral particles. The secondary particles included homogeneous mixed S-rich particles (HS) and organic coated S-rich particles (CS).

Table 2. Classification of individual aerosol particles.

\begin{tabular}{|c|c|c|}
\hline Types & Sub-Types & Physical and Chemical Characteristics \\
\hline \multirow{3}{*}{ Primary particles } & Mineral & $\begin{array}{l}\text { Irregular shaped; mainly composed } \mathrm{O}, \mathrm{Si}, \mathrm{Al}, \mathrm{Fe}, \mathrm{Ca}, \mathrm{Na} \text {, } \\
\mathrm{K}, \mathrm{Mg} \text {; soil, road dust and construction dust sources }\end{array}$ \\
\hline & Soot & $\begin{array}{l}\text { Aggregate shaped spheres; composed of } \mathrm{C} \text { and minor } \mathrm{O} \text {; } \\
\text { sourced from incomplete combustion. }\end{array}$ \\
\hline & Organic & $\begin{array}{l}\text { Spherical or near spherical shaped; composed of C } \\
\text { and O; combustion sources }\end{array}$ \\
\hline \multirow{2}{*}{ Secondary particles } & $\begin{array}{l}\text { Homogeneous mixed } \\
\text { S-rich particles (HS) }\end{array}$ & $\begin{array}{l}\text { Spherical or near spherical shaped; composed of } \mathrm{C}, \mathrm{S}, \mathrm{O} \text {, } \\
\mathrm{N} \text { and sometimes with minor K; beam-sensitive; } \\
\text { secondary formation in atmosphere }\end{array}$ \\
\hline & $\begin{array}{l}\text { Organic coated S-rich } \\
\text { particles }(\mathrm{CS})\end{array}$ & $\begin{array}{l}\text { Core-shell structure; composed of } \mathrm{C}, \mathrm{S}, \mathrm{O}, \mathrm{N} \text { and } \\
\text { sometimes with minor K; beam-sensitive; secondary } \\
\text { formation in atmosphere }\end{array}$ \\
\hline
\end{tabular}

Most of the mineral particles are irregularly shaped and tend to have a larger diameter than other particle types as shown in Figure 1a,b. Their elemental compositions are complex, consisting of $\mathrm{O}, \mathrm{Si}, \mathrm{Al}, \mathrm{Fe}, \mathrm{Ca}, \mathrm{Na}, \mathrm{K}, \mathrm{Mg}$ and $\mathrm{S}$. Mineral particles are mainly from suspension of soil, road dust, and construction dust. They can be also sourced from desert dust and undergo long rang transport [22]. Mineral particles are stable under strong electron beam irradiation.

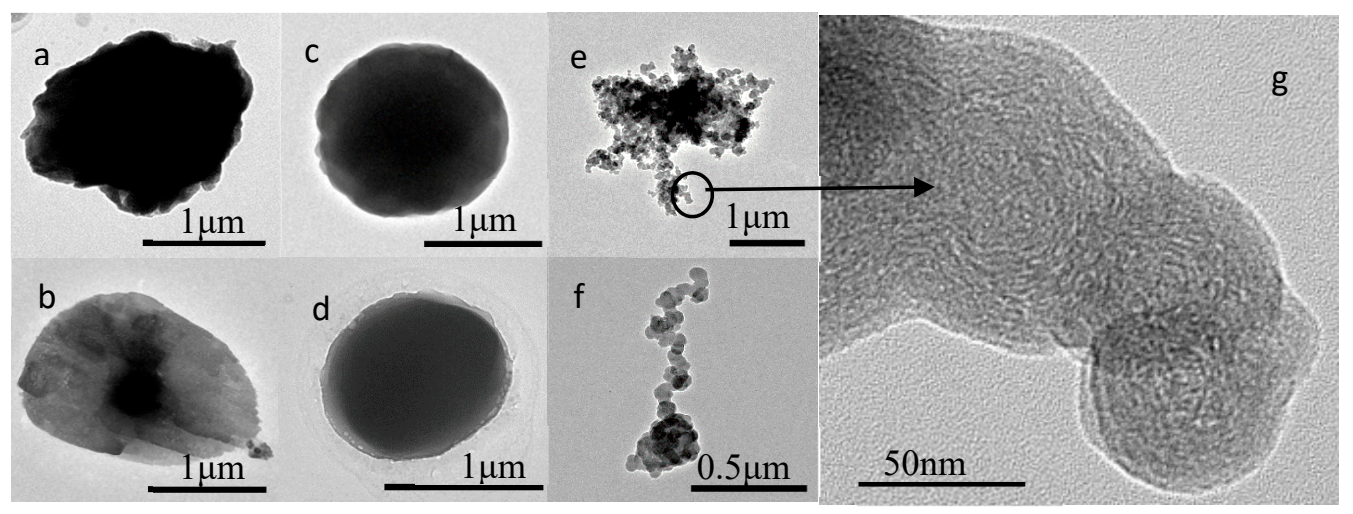

Figure 1. TEM images of primary individual particles: (a,b) mineral particles, (c) spherical organic particle, (d) near-spherical organic particle, (e) aged soot particle and (f) chain-like soot particle; (g) amplified soot spherical. 
Soot aggregates contain numbers of C-dominated spheres with diameter less than $100 \mathrm{~nm}$ (Figure 1e,f). High magnification TEM images demonstrate that typical soot spheres display the onion-like structures with disordered graphitic layers as shown in Figure 1g. They are from incomplete combustion of fossil fuels and other materials [23].

Organic particles show higher O proportion than soot aggregates, though they are both dominated by $\mathrm{C}$ and $\mathrm{O}$. Organic particles lack onion-like structure under high magnification TEM images, compared with soot particles. Most of the organic particles in this study are spherical or near spherical shaped. Li and Shao suggest that the primary organic particles normally have a spherical or irregular shape [24]. They are from combustion sources.

Different from primary particle types, the secondary particles are beam-sensitive when exposed to several seconds of beam irradiation. These secondary particles are mainly composed of element $C$, $\mathrm{O}, \mathrm{S}$ and minor $\mathrm{N}$ and are defined as S-rich particles $[18,20]$. We infer that they indeed are mixtures of sulfate, nitrate, and/or organic matter (OM) in the atmosphere [18]. Although the secondary particles have similar elemental compositions, they show different mixing states and thus are further classified into HS and CS particles.

HS particles are foam-like as shown in Figure 2a,b. Although they are not strictly evenly distributed, we term these particles as homogeneous mixed S-rich particles (HS). Although HS particles look similar in the TEM images, they may display different optical and/or hygroscopic properties because of their mass fractions of sulfate, OM, and/or nitrate [22]. Apart from HS particles, we also find some secondary particles with organic coating. These core-shell particles clearly show an uneven surface, as shown in Figure 2c,d. When exposed to electron beam irradiation, the core disappeared, leaving some residues and an obvious shell structure as shown in Figure 2e,f. The organic shell and inorganic core have been certified by using a nanometer-scale secondary ion mass spectrometer (Nano-SIMS) according to Li et al. [25].

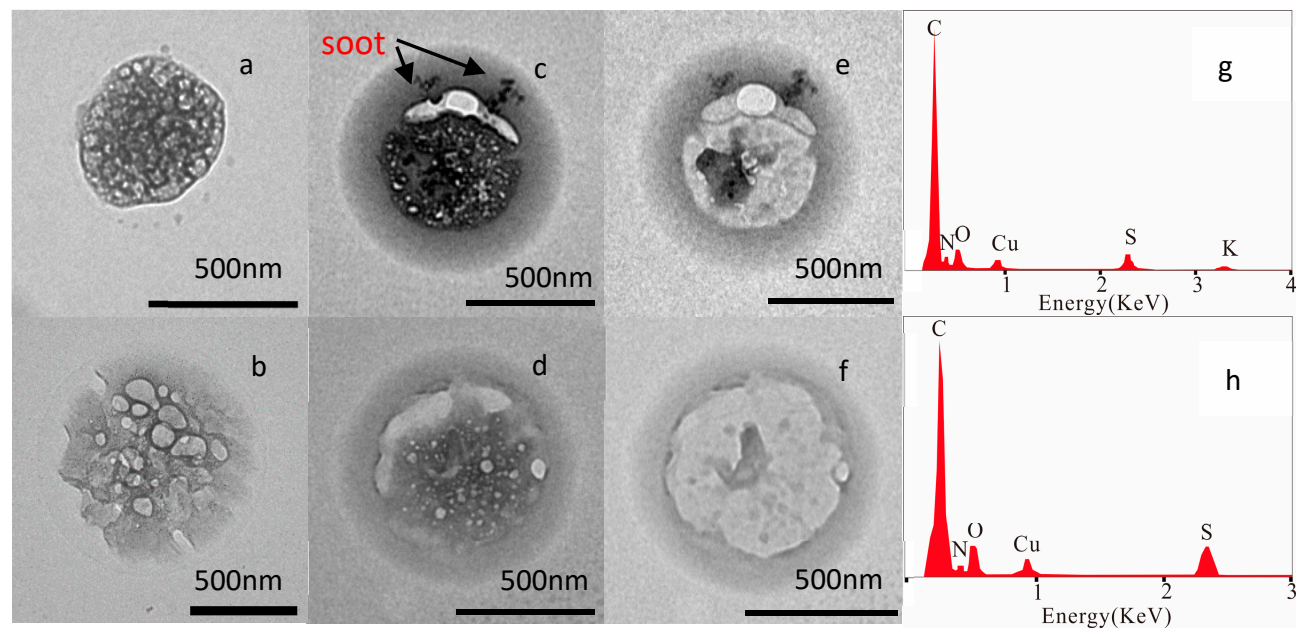

Figure 2. TEM images and elemental compositions of secondary particles: (a,b) HS particles, (c,d) CS particles, $(\mathbf{e}, \mathbf{f})$ images of $(\mathbf{c}, \mathbf{d})$ after electron beam exposure; $(\mathbf{g}, \mathbf{h})$ elemental compositions of $(\mathbf{c}, \mathbf{d})$.

\subsection{Relative Number Percentage and Size Distribution}

A total of 810 individual aerosol particles ( 336 for A, 246 for B and 228 for C) were analyzed in this study. Figure 3 shows the relative number percentage of individual aerosol particles. The results showed that there was a large proportion of secondary particles because of the strict emission control measures. During the 2015 China Victory Day parade control periods, HS particles and CS particles represent the major fraction with $44.9 \%$ and $34.3 \%$, respectively, followed by mineral particles $(10.5 \%)$, soot aggregates $(7.21 \%)$ and organic particles (3.2\%; Figure 3$)$. Soot aggregates and organic particles show relative lower number percentage. It is consistent with Wang et al. [26], who reported that 
both the primary organic carbon and elemental carbon had the relative lower proportion during the control period.

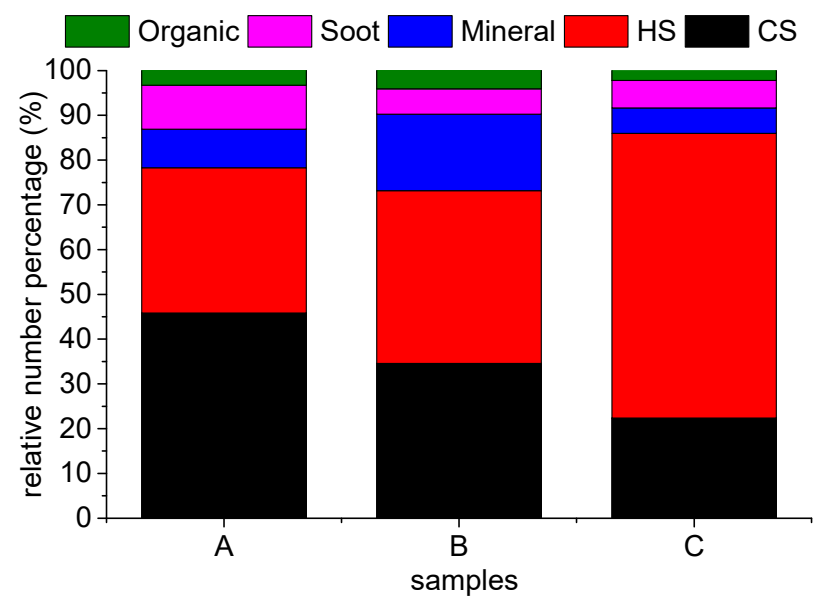

Figure 3. Relative number percentage of individual particles (Homogeneous mixed S-rich particles, HS; Core-shell structured S-rich particles, CS).

Equivalent circle diameter of secondary particles were obtained according to the image analysis software (Leica, UK). Number-size distributions of 639 secondary particles (including HS and CS particles) ranged from 0.1 to $1.0 \mu \mathrm{m}$ are shown in Figure 4 . The average diameter of secondary particles increases with RH, being $323 \mathrm{~nm}, 358 \mathrm{~nm}$ and $397 \mathrm{~nm}$ at the $\mathrm{RH} 34 \%, 43 \%$ and 53\%, respectively. In addition, with the increase of $\mathrm{RH}$, the peak shifts to the right side of the coordinate, suggesting that the high RH can favor the growth of secondary particles.

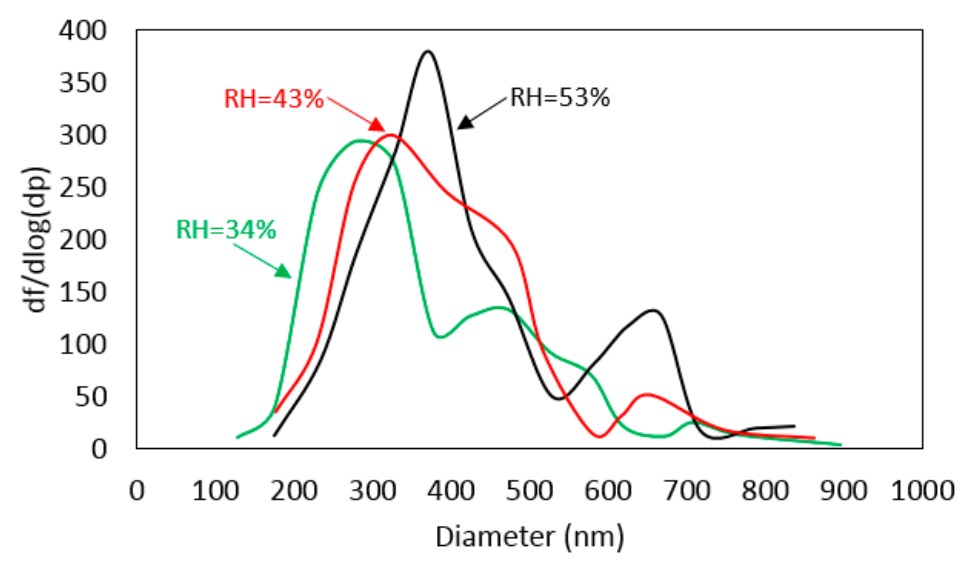

Figure 4. Size distributions of secondary particles at RH $34 \%, 43 \%$ and $53 \%$.

\section{Discussion and Atmospheric Implication}

\subsection{Influence of RH on Secondary Particle Formation}

The secondary particles showed a higher proportion in number, accounting for $79.2 \%$. This is consistent with Zhao et al., who reported that the primary species showed relatively more reductions (55-67\%) than secondary aerosol species (33-44\%) during the control periods [15]. The HS particles are the major fraction of aerosol particles and they increase with the increasing of $\mathrm{RH}$, being $32.4 \%, 38.6 \%$ and $64.6 \%$ at $\mathrm{RH} 34 \%, 43 \%$ and $53 \%$, respectively. The formation of S-rich particles might be affected by a number of factors. The wind direction is mainly from the southern part and the wind speed is 
comparable during our sampling time in Beijing [27]. The average hourly ozone concentration is 77, 51 and $74 \mu \mathrm{g} / \mathrm{m}^{3}$, for samples A, B and C, respectively (https://www.aqistudy.cn/). Both the wind and ozone concentration showed no obvious correlation with the relative number percentage of HS particles. So, we suggest that high RH can favor the formation of HS particles. This is consistent with a previous study by Wang et al. in Beijing during the pollution periods that the S-rich particles were correlated with RH [28].

Water can be a major component of aerosol particles, and serves as a medium for aqueous-phase reactions [29]. Uptake of water by atmospheric particles modifies the mass of the aerosol particle and increases the particle size $[30,31]$. Previous studies have shown that particle diameter increases with increasing $\mathrm{RH}$ [32]. For example, experimental study demonstrated that when exposed to $\mathrm{SO}_{2}$, $\mathrm{NO}_{2}$, and $\mathrm{NH}_{3}$, the growth factor of the seed particles increased with $\mathrm{RH}$, with the values of near unity at $\mathrm{RH}<20 \%$ and 2.3 at $70 \% \mathrm{RH}$ [33]. We admit that the particles collected by impaction may potentially be flattened and the secondary particles at different RH might show different viscosity [34], having different flattened ability. However, the larger secondary particles in the atmosphere will generally have a larger flatten size on the filter. Therefore, the absolute diameter of the flattened particles may be different from the diameter of the particles in the atmosphere, but the increasing sizes for the impacted particles should represent the increasing trend of the particle diameters in atmosphere. Figure 4 showed that the average diameter of secondary particles increased with the increasing of RH, suggesting that higher $\mathrm{RH}$ can favor the growth of secondary particles. Our result is consistent with previous "bulk" sample analysis, which reported the higher RH promotes the secondary particle formation. For example, Wang et al. found the conversion of $\mathrm{SO}_{2}$ to $\mathrm{SO}_{4}{ }^{2-}$ not only contributes to the high production rate, but also enhances formations of $\mathrm{NO}_{3}{ }^{-}$and $\mathrm{SOA}$ on aqueous particles because of increasing particle hygroscopicity [33]. Liu et al. found that sulfates, together with nitrates, significantly contribute to wintertime air pollution in Beijing and suggested that the sulfate is due to heterogeneous reaction with abundant aerosol water under wet conditions [35].

\subsection{Atmospheric Implication of CS Particles}

The CS particles accounted for a large proportion with $34.3 \%$ in our samples. Core-shell morphology is prevalent configuration of tropospheric particles. They were also found in other sampling sites, but showed proportional difference; there are proportionally higher CS particles in mountain Tai, Greater Khingan and rural background sampling site, but less in urban and suburban-polluted air in Beijing and no CS particles in biomass and coal burning sourced particles [18].

When the atmospheric S-rich particles are coated with OM, they can lead to important implications for a wide range of climate-relevant endpoints as well as air quality predictions. The OM coating can change a host particle's early hygroscopic properties [36,37]. They can influence the RH at which crystallization and dissolution of sulfate solids occur in atmospheric particles [38], change the partitioning of semi volatile organic compounds between the gas and particle phase [39,40], and alter the scattering and absorption of solar radiation. In atmospheric chemistry, the heterogeneous reactions of gas-phase species (such as ozone or $\mathrm{N}_{2} \mathrm{O}_{5}$ ) on the surface of aerosol particles play an important role in the removal of species that affect the oxidative balance of the atmosphere [41]. If the ammonium sulfate is surrounded by the organic-rich phase, the $\mathrm{N}_{2} \mathrm{O}_{5}$ uptake may be reduced effectively influenced by the hygroscopicity and viscosity of the organic shell [42], leading to the increased concentrations of gas-phase $\mathrm{NO}_{3}$ and $\mathrm{N}_{2} \mathrm{O}_{5}$ and changing the mixing ratios of $\mathrm{N}_{2} \mathrm{O}_{5}, \mathrm{NO}_{3}$, particle phase nitrate, and volatile organic compounds [43].

\subsection{Possible Phase Transformation of CS Particles}

Secondary aerosols, formed by gas-to-particle phase conversion, account for a large proportion of total particles in our samples (Figure 3). The formation mechanism of the organic coated S-rich particles remains with some uncertainties. They may be formed by liquid-liquid phase separation under the 
various RH from high to low values [44] or by condensation of secondary organic compounds on the pre-existing inorganic aerosols $[18,45]$.

Some researchers suggest that the well mixed secondary particles may undergo liquid-liquid phase separation under a lower $\mathrm{RH}$, and the process would change the particles into the core-shell structures, typified by an organic core and an inorganic shell. For example, various "bulk" sample analyses conducted in the laboratory have confirmed the liquid-liquid phase separation do exist for the secondary particles [41,46,47]. The presence of the organic core and inorganic shell in individual particles have been confirmed in the laboratory by using optical microscopy and Raman spectroscopy [38,41,42], atomic force microscopy with infrared spectroscopy [48], and environmental scanning electron microscopy and scanning transmission X-ray microscopy [49].

However, previous studies have demonstrated that the liquid-liquid phase separation is not observed for the organic species having $\mathrm{O} / \mathrm{C}$ ratio greater than 0.8 [44]. The average $\mathrm{O} / \mathrm{C}$ ratios of secondary organic aerosols ranged from 0.84 to 1.0 , higher than 0.8 , during the control periods [15]. The higher $\mathrm{O} / \mathrm{C}$ ratios of secondary organic aerosols during our sampling periods will not favor the Liquid-liquid phase separation process.

Hou et al. noticed that the secondary S-rich particles can be coated with the secondary organic aerosols, and that the thickness of the organic coatings will increase with the particle's aging [45]. During the control period, the organic aerosols accounted for a larger proportion in the total particles, and they were mostly secondary organic aerosols [26]. Therefore, we believe that the CS particles collected during the control periods were formed by the condensation of secondary organic compounds on pre-existing S-rich particles, instead of liquid-liquid phase separation. When the RH increases, the liquid-liquid mixing may occur on the CS particles again, forming a HS particle.

\section{Conclusions}

During the 2015 China Victory Day parade control periods, individual aerosol particles were analyzed. Based on the morphologies and elemental compositions, five types of individual particles were identified, which were further classified into two groups, including primary particles (mineral particles, soot aggregates, organic particles) and secondary particles (HS particles and CS particles). Among the 810 individual particles, secondary particles accounted for a large proportion at $79.2 \%$. HS and CS particles were predominant with $44.9 \%$ and $34.3 \%$, respectively, followed by mineral particles $(10.5 \%)$, soot aggregates $(7.2 \%)$ and organic particles $(3.2 \%)$.

The average diameter of secondary particles increases with RH, being $323 \mathrm{~nm}, 358 \mathrm{~nm}$ and $397 \mathrm{~nm}$ at the $\mathrm{RH} 34 \%, 43 \%$ and $53 \%$, respectively, suggesting that the high $\mathrm{RH}$ favor the growth of secondary particles. The CS particles may be formed by the condensation of secondary organic aerosols on pre-existing S-rich particles under the lower RH in this study.

Acknowledgments: This work was supported by the Projects of International Cooperation and Exchanges NSFC (Grant No. 41571130031) and National Basic Research Program of China (Grant No. 2013CB228503).

Author Contributions: Longyi Shao and Wenhua Wang conceived and designed the experiments; Wenhua Wang, Jie Li and Lingli Chang performed the experiments; Jiaoping Xing and Wenjun Li analyzed the data; Wenhua Wang and Longyi Shao wrote the paper.

Conflicts of Interest: The authors declare no conflict of interest.

\section{References}

1. Huang, R.J.; Zhang, Y.; Bozzetti, C.; Ho, K.F.; Cao, J.J.; Han, Y.; Daellenbach, K.R.; Slowik, J.G.; Platt, S.M.; Canonaco, F.; et al. High secondary aerosol contribution to particulate pollution during haze events in China. Nature 2014, 514, 218-222. [CrossRef] [PubMed]

2. West, J.J.; Cohen, A.; Dentener, F.; Brunekreef, B.; Zhu, T.; Armstrong, B.; Bell, M.L.; Brauer, M.; Carmichael, G.; Costa, D.L.; et al. What We Breathe Impacts Our Health: Improving Understanding of the Link between Air Pollution and Health. Environ. Sci. Technol. 2016, 50, 4895-4904. [CrossRef] [PubMed] 
3. Shao, L.Y.; Hu, Y.; Shen, R.; Schäfer, K.; Wang, J.; Wang, J.; Schnelle-Kreis, J.; Zimmermann, R.; BéruBé, K.; Suppan, P. Seasonal variation of particle-induced oxidative potential of airborne particulate matter in Beijing. Sci. Total Environ. 2017, 579, 1152-1160. [CrossRef] [PubMed]

4. Planche, C.; Mann, G.W.; Carslaw, K.S.; Dalvi, M.; Marsham, J.H.; Field, P.R. Spatial and temporal CCN variations in convection-permitting aerosol microphysics simulations in an idealised marine tropical domain. Atmos. Chem. Phys. 2017, 17, 3371-3384. [CrossRef]

5. Phillips, V.T.J.; DeMott, P.J.; Andronache, C. An empirical parameterization of heterogeneous ice nucleation for multiple chemical species of aerosol. J. Atmos. Sci. 2008, 65, 2757-2783. [CrossRef]

6. Chen, B.; Zhu, Z.; Wang, X.; Andersson, A.; Chen, J.; Zhang, Q.; Gustafsson, Ö. Reconciling modeling with observations of radiative absorption of black carbon aerosols. J. Geophys. Res. Atmos. 2017, 122, 5932-5942. [CrossRef]

7. Tao, J.; Zhang, L.; Ho, K.; Zhang, R.; Lin, Z.; Zhang, Z.; Lin, M.; Cao, J.; Liu, S.; Wang, G. Impact of PM2.5 chemical compositions on aerosol light scattering in Guangzhou-The largest megacity in South China. Atmos. Res. 2014, 135, 48-58. [CrossRef]

8. Heald, C.L.; Jacob, D.J.; Park, R.J.; Alexander, B.; Fairlie, T.D.; Yantosca, R.M.; Chu, D.A. Transpacific transport of Asian anthropogenic aerosols and its impact on surface air quality in the United States. J. Geophys. Res. Atmos. 2006, 111, D14. [CrossRef]

9. Ma, Q.X.; Wu, Y.; Zhang, D.; Wang, X.; Xia, Y.; Liu, X.; Tian, P.; Han, Z.; Xia, X.; Wang, Y. Roles of regional transport and heterogeneous reactions in the $\mathrm{PM}_{2.5}$ increase during winter haze episodes in Beijing. Sci. Total Environ. 2017, 599, 246-253. [CrossRef] [PubMed]

10. Zhang, X.Y.; Wang, Y.Q.; Niu, T.; Zhang, X.C.; Gong, S.L.; Zhang, Y.M.; Sun, J.Y. Atmospheric aerosol compositions in China: Spatial/temporal variability, chemical signature, regional haze distribution and comparisons with global aerosols. Atmos. Chem. Phys. 2012, 12, 779-799. [CrossRef]

11. Zhang, F.; Wang, L.; Yang, J.; Chen, M.; Wei, Z.; Su, J. The characteristics of air pollution episodes in autumn over the southern Hebei, China. World J. Eng. 2015, 12, 221-236. [CrossRef]

12. Niu, H.; Cheng, W.; Pian, W.; Hu, W. The physicochemical properties of submicron particles from emissions of industrial furnace. World J. Eng. 2016, 13, 218-224. [CrossRef]

13. Posfai, M.; Buseck, P.R. Nature and Climate Effects of Individual Tropospheric Aerosol Particles. Rev. Earth Planet. Sci. 2010, 38, 17-43. [CrossRef]

14. Liu, S.; Aiken, A.C.; Gorkowski, K.; Dubey, M.K.; Cappa, C.D.; Williams, L.R.; Herndon, S.C.; Massoli, P.; Fortner, E.C.; Chhabra, P.S.; et al. Enhanced light absorption by mixed source black and brown carbon particles in UK winter. Nat. Commun. 2015, 6, 10. [CrossRef] [PubMed]

15. Zhao, J.; Du, W.; Zhang, Y.; Wang, Q.; Chen, C.; Xu, W.; Han, T.; Wang, Y.; Fu, P.; Wang, Z.; et al. Insights into aerosol chemistry during the 2015 China Victory Day parade: Results from simultaneous measurements at ground level and $260 \mathrm{~m}$ in Beijing. Atmos. Chem. Phys. 2017, 17, 3215-3232. [CrossRef]

16. Wang, T.; Nie, W.; Gao, J.; Xue, L.K.; Gao, X.M.; Wang, X.; Qiu, J.; Poon, C.N.; Meinardi, S.; Blake, D.; Wang, S.L. Air quality during the 2008 Beijing Olympics: Secondary pollutants and regional impact. Atmos. Chem. Phys. 2010, 10, 7603-7615. [CrossRef]

17. Chen, C.; Sun, Y.L.; Xu, W.Q.; Du, W.; Zhou, L.B.; Han, T.T.; Wang, Q.Q.; Fu, P.Q.; Wang, Z.F.; Gao, Z.Q.; et al. Characteristics and sources of submicron aerosols above the urban canopy (260 m) in Beijing, China, during the 2014 APEC summit. Atmos. Chem. Phys. 2015, 15, 12879-12895. [CrossRef]

18. Li, W.J.; Sun, J.; Xu, L.; Shi, Z.; Riemer, N.; Sun, Y.; Fu, P.; Zhang, J.; Lin, Y.; Wang, X.; et al. A conceptual framework for mixing structures in individual aerosol particles. J. Geophys. Res. Atmos. 2016, 121, 13784-13798. [CrossRef]

19. Li, W.J.; Shao, L.Y. Characterization of mineral particles in winter fog of Beijing analyzed by TEM and SEM. Environ. Monit. Assess. 2010, 161, 565-573. [CrossRef] [PubMed]

20. Xu, L.; Liu, L.; Zhang, J.; Zhang, Y.; Ren, Y.; Wang, X.; Li, W. Morphology, composition, and mixing state of individual aerosol particles in Northeast China during wintertime. Atmosphere 2017, 8, 10. [CrossRef]

21. Xing, J.P.; Shao, L.; Zheng, R.; Peng, J.; Wang, W.; Guo, Q.; Wang, Y.; Qin, Y.; Shuai, S.; Hu, M. Individual particles emitted from gasoline engines: Impact of engine types, engine loads and fuel components. J. Clean. Prod. 2017, 149, 461-471. [CrossRef] 
22. Li, W.J.; Shao, L.; Zhang, D.; Ro, C.U.; Hu, M.; Bi, X.; Geng, H.; Matsuki, A.; Niu, H.; Chen, J. A review of single aerosol particle studies in the atmosphere of East Asia: Morphology, mixing state, source, and heterogeneous reactions. J. Clean. Prod. 2016, 112, 1330-1349. [CrossRef]

23. China, S.; Scarnato, B.; Owen, R.C.; Zhang, B.; Ampadu, M.T.; Kumar, S.; Dzepina, K.; Dziobak, M.P.; Fialho, P.; Perlinger, J.A.; et al. Morphology and mixing state of aged soot particles at a remote marine free troposphere site: Implications for optical properties. Geophys. Res. Lett. 2015, 42, 1243-1250. [CrossRef]

24. Li, W.J.; Shao, L.Y. Mixing and water-soluble characteristics of particulate organic compounds in individual urban aerosol particles. J. Geophys. Res. Atmos. 2010, 115, 9. [CrossRef]

25. Ghosal, S.; Weber, P.K.; Laskin, A. Spatially resolved chemical imaging of individual atmospheric particles using nanoscale imaging mass spectrometry: Insight into particle origin and chemistry. Anal. Methods 2014, 6, 2444-2451. [CrossRef]

26. Wang, Y.; Xue, Y.; Tian, H.; Gao, J.; Chen, Y.; Zhu, C.; Liu, H.; Wang, K.; Hua, S.; Liu, S.; et al. Effectiveness of temporary control measures for lowering $\mathrm{PM}_{2.5}$ pollution in Beijing and the implications. Atmos. Environ. 2017, 157, 75-83. [CrossRef]

27. Wang, Z.S.; Li, Y.T.; Zhang, D.W.; Chen, T.; Wei, Q.; Sun, T.H.; Wang, B.Y.; Pan, J.X.; Cui, J.X.; Pi, S. Analysis on air quality in Beijing during the military parade period in 2015. China Environ. Sci. 2017, 37, 1628-1636. (In Chinese)

28. Wang, W.; Shao, L.; Guo, M.; Hou, C.; Xing, J.; Wu, F. Physicochemical properties of individual airborne particles in Beijing during pollution periods. Aerosol Air Qual. Res. 2017, 17, 3209-3219. [CrossRef]

29. Bian, Y.X.; Zhao, C.S.; Ma, N.; Chen, J.; Xu, W.Y. A study of aerosol liquid water content based on hygroscopicity measurements at high relative humidity in the North China Plain. Atmos. Chem. Phys. 2014, 14, 6417-6426. [CrossRef]

30. Villani, P.; Sellegri, K.; Monier, M.; Laj, P. Influence of semi-volatile species on particle hygroscopic growth. Atmos. Environ. 2013, 79, 129-137. [CrossRef]

31. Fajardo, O.A.; Jiang, J.K.; Hao, J.M. Continuous Measurement of Ambient Aerosol Liquid Water Content in Beijing. Aerosol Air Qual. Res. 2016, 16, 1152-1164. [CrossRef]

32. Liu, Y.C.; Wu, Z.; Tan, T.; Wang, Y.; Qin, Y.; Zheng, J.; Li, M.; Hu, M. Estimation of the PM 2.5 effective hygroscopic parameter and water content based on particle chemical composition: Methodology and case study. Sci. China-Earth Sci. 2016, 59, 1683-1691. [CrossRef]

33. Wang, G.H.; Zhang, R.; Gomez, M.E.; Yang, L.; Zamora, M.L.; Hu, M.; Lin, Y.; Peng, J.; Guo, S.; Meng, J.; et al. Persistent sulfate formation from London Fog to Chinese haze. Proc. Natl. Acad. Sci. USA 2016, 113, 13630-13635. [CrossRef] [PubMed]

34. Song, M.; Liu, P.F.; Hanna, S.J.; Li, Y.J.; Martin, S.T.; Bertram, A.K. Relative humidity-dependent viscosities of isoprene-derived secondary organic material and atmospheric implications for isoprene-dominant forests. Atmos. Chem. Phys. 2015, 15, 5145-5159. [CrossRef]

35. Liu, Z.R.; Hu, B.; Zhang, J.; Yu, Y.; Wang, Y. Characteristics of aerosol size distributions and chemical compositions during wintertime pollution episodes in Beijing. Atmos. Res. 2016, 168, 1-12. [CrossRef]

36. Semeniuk, T.A.; Wise, M.E.; Martin, S.T.; Russell, L.M.; Buseck, P.R. Water uptake characteristics of individual atmospheric particles having coatings. Atmos. Environ. 2007, 41, 6225-6235. [CrossRef]

37. Davies, J.F.; Miles, R.E.; Haddrell, A.E.; Reid, J.P. Influence of organic films on the evaporation and condensation of water in aerosol. Proc. Natl. Acad. Sci. USA 2013, 110, 8807-8812. [CrossRef] [PubMed]

38. Song, M.J.; Marcolli, C.; Krieger, U.K.; Lienhard, D.M.; Peter, T. Morphologies of mixed organic/inorganic/ aqueous aerosol droplets. Faraday Discuss. 2013, 165, 289-316. [CrossRef] [PubMed]

39. Zuend, A.; Marcolli, C.; Peter, T.; Seinfeld, J.H. Computation of liquid-liquid equilibria and phase stabilities: Implications for RH-dependent gas/particle partitioning of organic-inorganic aerosols. Atmos. Chem. Phys. 2010, 10, 7795-7820. [CrossRef]

40. Schill, G.P.; Tolbert, M.A. Heterogeneous ice nucleation on phase-separated organic-sulfate particles: Effect of liquid vs. glassy coatings. Atmos. Chem. Phys. 2013, 13, 4681-4695. [CrossRef]

41. Stewart, D.J.; Cai, C.; Nayler, J.; Preston, T.C.; Reid, J.P.; Krieger, U.K.; Marcolli, C.; Zhang, Y.H. Liquid-Liquid Phase Separation in Mixed Organic/Inorganic Single Aqueous Aerosol Droplets. J. Phys. Chem. A 2015, 119, 4177-4190. [CrossRef] [PubMed] 
42. Song, M.; Marcolli, C.; Krieger, U.K.; Zuend, A.; Peter, T. Liquid-liquid phase separation and morphology of internally mixed dicarboxylic acids/ammonium sulfate/water particles. Atmos. Chem. Phys. 2012, 12, 2691-2712. [CrossRef]

43. You, Y.; Renbaum-Wolff, L.; Carreras-Sospedra, M.; Hanna, S.J.; Hiranuma, N.; Kamal, S.; Smith, M.L.; Zhang, X.; Weber, R.J.; Shilling, J.E.; et al. Images reveal that atmospheric particles can undergo liquid-liquid phase separations. Proc. Natl. Acad. Sci. USA 2012, 109, 13188-13193. [CrossRef] [PubMed]

44. You, Y.; Smith, M.L.; Song, M.; Martin, S.T.; Bertram, A.K. Liquid-liquid phase separation in atmospherically relevant particles consisting of organic species and inorganic salts. Int. Rev. Phys. Chem. 2014, 33, 43-77. [CrossRef]

45. Hou, C.; Shao, L.; Hu, W.; Zhang, D.; Zhao, C.; Xing, J.; Huang, X.; Hu, M. Characteristics and aging of traffic-derived particles in a highway tunnel at a coastal city in southern China. Sci. Total Environ. 2018, 619, 1385-1393. [CrossRef]

46. Marcolli, C.; Krieger, U.K. Phase changes during hygroscopic cycles of mixed organic/inorganic model systems of tropospheric aerosols. J. Phys. Chem. A 2006, 110, 1881-1893. [CrossRef] [PubMed]

47. Hodas, N.; Zuend, A.; Mui, W.; Flagan, R.C.; Seinfeld, J.H. Influence of particle-phase state on the hygroscopic behavior of mixed organic-inorganic aerosols. Atmos. Chem. Phys. 2015, 15, 5027-5045. [CrossRef]

48. Bondy, A.L.; Kirpes, R.M.; Merzel, R.L.; Pratt, K.A.; Banaszak Holl, M.M.; Ault, A.P. Atomic Force Microscopy-Infrared Spectroscopy of Individual Atmospheric Aerosol Particles: Subdiffraction Limit Vibrational Spectroscopy and Morphological Analysis. Anal. Chem. 2017, 89, 8594-8598. [CrossRef] [PubMed]

49. O'Brien, R.E.; Wang, B.; Kelly, S.T.; Lundt, N.; You, Y.; Bertram, A.K.; Leone, S.R.; Laskin, A.; Gilles, M.K. Liquid-Liquid Phase Separation in Aerosol Particles: Imaging at the Nanometer Scale. Environ. Sci. Technol. 2015, 49, 4995-5002. [CrossRef] [PubMed]

(C) 2018 by the authors. Licensee MDPI, Basel, Switzerland. This article is an open access article distributed under the terms and conditions of the Creative Commons Attribution (CC BY) license (http://creativecommons.org/licenses/by/4.0/). 